\title{
Dengue 2 infection of HepG2 liver cells results in endoplasmic reticulum stress and induction of multiple pathways of cell death
}

\author{
Chutima Thepparit ${ }^{1 \dagger}$, Atefeh Khakpoor ${ }^{1 \dagger}$, Sarawut Khongwichit ${ }^{1 \dagger}$, Nitwara Wikan ${ }^{1}$, Chanida Fongsaran ${ }^{1}$, \\ Pimjai Chingsuwanrote ${ }^{1}$, Patcharee Panraksa ${ }^{1}$ and Duncan R Smith ${ }^{1,2^{*}}$
}

\begin{abstract}
Background: A number of studies have implicated the direct involvement of the liver in dengue virus (DENV) infection, and it has been widely shown that liver cells subsequently undergo apoptosis. The mechanism by which liver cells undergo apoptosis in response to DENV infection remains unclear. To provide further information on the mechanism of apoptosis in DENV infected liver cells, HepG2 cells were infected with DENV 2 and analyzed for the induction of ER stress, apoptosis and autophagy.

Results: In response to DENV infection, HepG2 cells showed the induction of both the ER resident unfolded protein response as well as the Noxa/PUMA stress response pathways. Proteolytic activation of caspases 4, 7, 8 and 9 was observed as well as changes in mitochondrial transmembrane potential. Increased monodansylcadaverine staining was observed in DENV infected cells, consistent with the previously reported induction of autophagy.

Conclusions: These results are consistent with a model in which the induction of multiple ER stress pathways is coupled with the induction of multiple cell death pathways as a mechanism to ensure the removal of infected liver cells from the system.
\end{abstract}

Keywords: Apoptosis, Autophagy, Caspase, Dengue, ER stress liver

\section{Background}

Dengue virus (DENV; family Flaviviridae, genus Flavivirus) is the causative agent of dengue, a mosquitotransmitted viral disease. In humans infection results in a wide range of clinical manifestations from a relatively self-limiting febrile illness termed dengue fever (DF) to more severe forms that can threaten the patient's life through plasma leakage in dengue haemorrhagic fever (DHF) and dengue shock syndrome (DSS) [1]. An estimated 390 million dengue infections are believed to occur each year, of which some nearly 100 million show manifestation of the disease at some severity level [2]. The involvement of the liver in the pathogenesis of dengue is suggested by evidence of hepatomegaly in dengue

\footnotetext{
* Correspondence: duncan_r_smith@hotmail.com

${ }^{\dagger}$ Equal contributors

'Molecular Pathology Laboratory, Institute of Molecular Biosciences, Mahidol University, 25/25 Phuttamontol Sai 4, Salaya, Nakorn Pathom 73170, Thailand

${ }^{2}$ Center for Emerging and Neglected Infectious Diseases, Mahidol University, Bangkok, Thailand
}

(c) 2013 Thepparit et al.; licensee BioMed Central Ltd. This is an Open Access article distributed under the terms of the Creative Commons Attribution License (http://creativecommons.org/licenses/by/2.0), which permits unrestricted use, distribution, and reproduction in any medium, provided the original work is properly cited.

patients [3] as well as the elevated levels of serum alanine aminotransferase and alkaline phosphatase $[4,5]$. Direct evidence of the involvement of the liver in the disease arises from studies that have shown the presence of dengue viral antigens in samples of human liver from fatal cases of dengue disease [6-9].

The presence of councilman bodies (believed to be the remains of cells undergoing apoptosis) have also been observed in specimens of liver collected at autopsy [9-11], and both primary kupffer cells and hepatocytes undergo apoptosis in response to DENV infection $[12,13]$, although only the latter cell type is productively infected. Several studies have investigated the mechanism of apoptosis induction in liver cell lines in response to DENV infection, although little consensus has emerged as to which cell death pathway or pathways are triggered, or how the process is initiated [14-18].

We have recently shown in monocytic cells that DENV infection results in the induction of the unfolded protein 
response (UPR) and the Noxa/PUMA (p53 upregulated modulator of apoptosis) endoplasmic reticulum (ER) stress pathways, and that coupled with this is the activation of both intrinsic and extrinsic apoptosis pathways [19]. Intrinsic apoptosis pathways are primarily mediated through mitochondria and are typified by the proteolytic activation of caspase 9, while extrinsic apoptosis is characterized by the involvement of death receptors and typified by the proteolytic activation of caspase 8 [20].

The primary function of the UPR is to adapt to changes in the environment and reestablish normal ER function [21]. The central mediator of the ER stress response is GRP78 (Glucose regulated protein 78 or BiP, Immunoglobulin heavy chain binding protein) and under normal conditions GRP78 binds to three critical ER transmembrane signaling proteins IRE1 (Inositol-requiring protein 1), ATF6 (Activating transcription factor 6), and PERK (Protein kinase RNA-like endoplasmic reticulum kinase) [22]. These three genes play a critical role in the adaptation mechanism by inducing the transcription of ER resident chaperones, blocking the translation of mRNAs in order to reduce the flux of the newly synthesized proteins to the ER, and increasing the amount of protein degradation [21-23]. Upon ER stress, GRP78 releases IRE1 and PERK leading to homodimerization and autophosphorylation and subsequent activation of each protein. Activated IRE1 excises a 26-nucleotide intron from the XBP-1 (Xbox binding protein) transcript producing a transcription factor that induces the expression of ER resident chaperons or proteins involved in the degradation process [24]. Oligomerized and phosphorylated PERK blocks the translation of most cytoplasmic mRNAs by phosphorylating eukaryotic initiation factor $2 \alpha$ (eIF-2 $\alpha$ ) and activating the expression of further downstream genes which are primarily involved in the regulation of apoptosis [25]. In contrast, upon release from GRP78, ATF6 is cleaved in the Golgi compartment by site protease 1 and 2 (sp1, sp2) and the cleaved form activates the expression of further chaperones and other downstream genes [22,23]. Both IRE1and ATF6 activation result in the up-regulation of GRP78 and as such increased levels of GRP78 are a hallmark of UPR induction [22,26-30].

Although the UPR is primarily a cell survival mechanism [22], where the stress is unrelieved, apoptosis, mediated by cross talk between the ER and mitochondria, is activated $[31,32]$. At least four pathways have been documented which act respectively through caspase 12 [33,34], CHOP (CCAAT/Enhancer-Binding Protein Homologous Protein) [35,36], JNK (C-Jun N-terminal kinase) [37] and $\mathrm{Ca}^{2+}[38,39]$. In addition to the UPR response, the Noxa/ PUMA pathway which is transcriptionally regulated by p53 is also activated under conditions of ER stress and leads to the eventual induction of apoptosis [40].
This study sought to comprehensively characterize the induction of apoptosis in DENV 2 infected HepG2 cells, and to determine whether there was activation of multiple ER stress pathways consistent with our previous observations in monocytic cells [19].

\section{Results}

\section{Activation of ER stress response pathways}

In our previous study we observed that experiments on activation of the UPR are prone to misinterpretation when undertaken on cell cultures with a low percentage of infection. We therefore initially determined the percentage of infected HepG2 cells after infection with DENV-2 at m.o.i.s of 1 and 10. At 24 hours post infection, percentage infection was determined by flow cytometry after staining with an antibody directed against DENV E protein. Results (Figure 1a) showed that approximately $30 \%$ of cells were infected after infection at m.o.i. 1 , while nearly $60 \%$ of cells were infected when m.o.i 10 was used. An m.o.i. of 10 was used in all subsequent experiments.

To investigate the activation of the UPR pathway in response to DENV infection, DENV 2 (strain 16681) was used to infect HepG2 cells under standard conditions at 10 p.f.u./cell in parallel with mock infected and tunicamycin treated cells. Cells were harvested at various time points and examined for the presence of the ER stress specific splicing product of XBP-1 by RTPCR. Results show that both tunicamycin treated and DENV 2 infected HepG2 cells showed the presence of the spliced product of XBP-1 (Figure 1b) while no spliced product was seen in mock infected cells. The presence of a heteroduplex product was seen in all cells (tunicamycin treated, mock and dengue infected) as has been noted by others [41-43]. The presence of the spliced product of the XBP-1 transcript demonstrate the activation of the UPR by DENV 2 infection, in agreement with the previous study of Umareddy and colleagues [43] in A549 (human alveolar basal epithelial) cells, and Klomporn and colleagues in U937 monocytic cells [19].

As up-regulation of GRP78 is a common hallmark of UPR activation induction, [22,26-30] and in particular is up-regulated by the activation of XBP-1 [44], the level of GRP78 was examined by western blot analysis. Results showed the over-expression of GRP78 in response to DENV 2 infection (Figure 1c) as has been noted by others [45].

We next examined whether the UPR sensor molecule PERK was found in association with GRP78 (Figure 2a). As would be expected, in mock infected cells a high degree of colocalization was observed between GRP78 and PERK (mean Pearson correlation coefficient 0.75, 95\% CI 0.71-0.79). Infection with DENV 2 significantly 


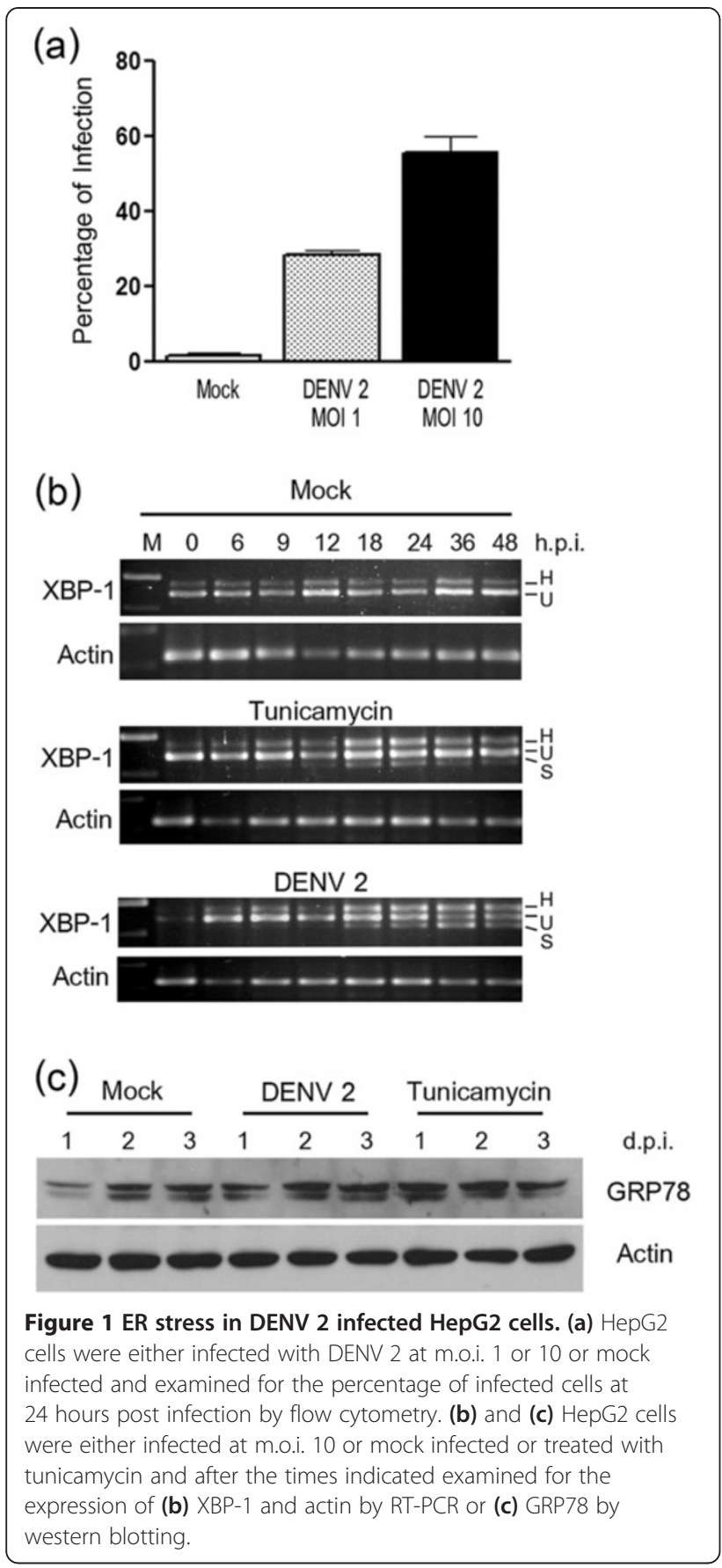

decreased the degree of colocalization (mean Pearson correlation coefficient $0.50,95 \%$ CI $0.47-0.55$; P $<0.001$ ). Similarly, a significantly lower colocalization was observed between GRP78 and ATF6 in DENV 2 infected cells (mean Pearson correlation coefficient 0.42 , 95\% CI 0.40-0.46 $\mathrm{p}<0.001$ ) in comparison to mock infected cells (mean Pearson correlation coefficient 0.8, 95\% CI 0.780.84) (Figure 2a).

Confocal analysis supported the western blot analysis showing over-expression of GRP 78 (Figure 2b). As previous reports have shown an interaction between GRP78 and DENV 2 E protein [46-48] and we have proposed that this interaction is serotype specific $[46,48]$ we therefore investigated the colocalization of DENV $2 \mathrm{E}$ protein in relationship to GRP78. A high level of colocalization between GRP78 and DENV 2 E protein was observed in DENV 2 infected samples (mean Pearson correlation coefficient 0.70) (Figure 2c).

Dissociation of PERK from GRP78 leads to oligomerization and activation of the cytosolic kinase domain which leads to the subsequent phosphorylation of eIF- $2 \alpha$. The phosphorylation of eIF- $2 \alpha$ was therefore investigated in DENV 2 infected HepG2 cells in parallel with tunicamycin treated control cells. Results (Figure 3a) showed an initial downregulation of phosphorylation of eIF- $2 \alpha$ and an increase on days 2 and 3 p.i. Similarly an initial down regulation of phosphorylation of eIF- $2 \alpha$ was observed in tunicamycin treated cells, but higher levels were observed on day 2 post treatment.

\section{Noxa, PUMA and CHOP}

Noxa and PUMA are transcriptionally regulated ER stress response genes that promote the induction of apoptosis. Expression of these two genes was examined by semi-quantitative RT-PCR. A clear induction of both genes was seen (Figure $3 \mathrm{~b}$ ), although induction of PUMA appeared to occur somewhat before the induction of Noxa. Similarly, a clear induction of CHOP was observed as early as 24 hours post infection (Figure 3c). These results were confirmed by real time PCR and expression of all three genes was shown to be significantly up regulated (See Figure 4). The delayed expression of Noxa as compared to PUMA was confirmed by the real time PCR analysis.

\section{Apoptosis}

In a previous study [18] we documented the induction of apoptosis in DENV 2 infected HepG2 cells through the observation of chromatin condensation, the presence of a DNA ladder and increased Annexin V/propidium iodide staining as well as a reduction in cell numbers in infected cultures as opposed to mock cultures. As that study was undertaken at a lower multiplicity of infection than the present study, we initially undertook a cell viability assay to determine whether a deficit in cell number was seen under the higher infection conditions, and whether this was associated with increased numbers of apoptotic cells as assessed by Annexin V/propidium iodide staining. Results (Figure 5) confirmed our previous observations at the lower multiplicity of infection. We further documented clear morphological changes in DENV 2 infected HepG2 cells as opposed to mock infected cell (Figure 6a). 


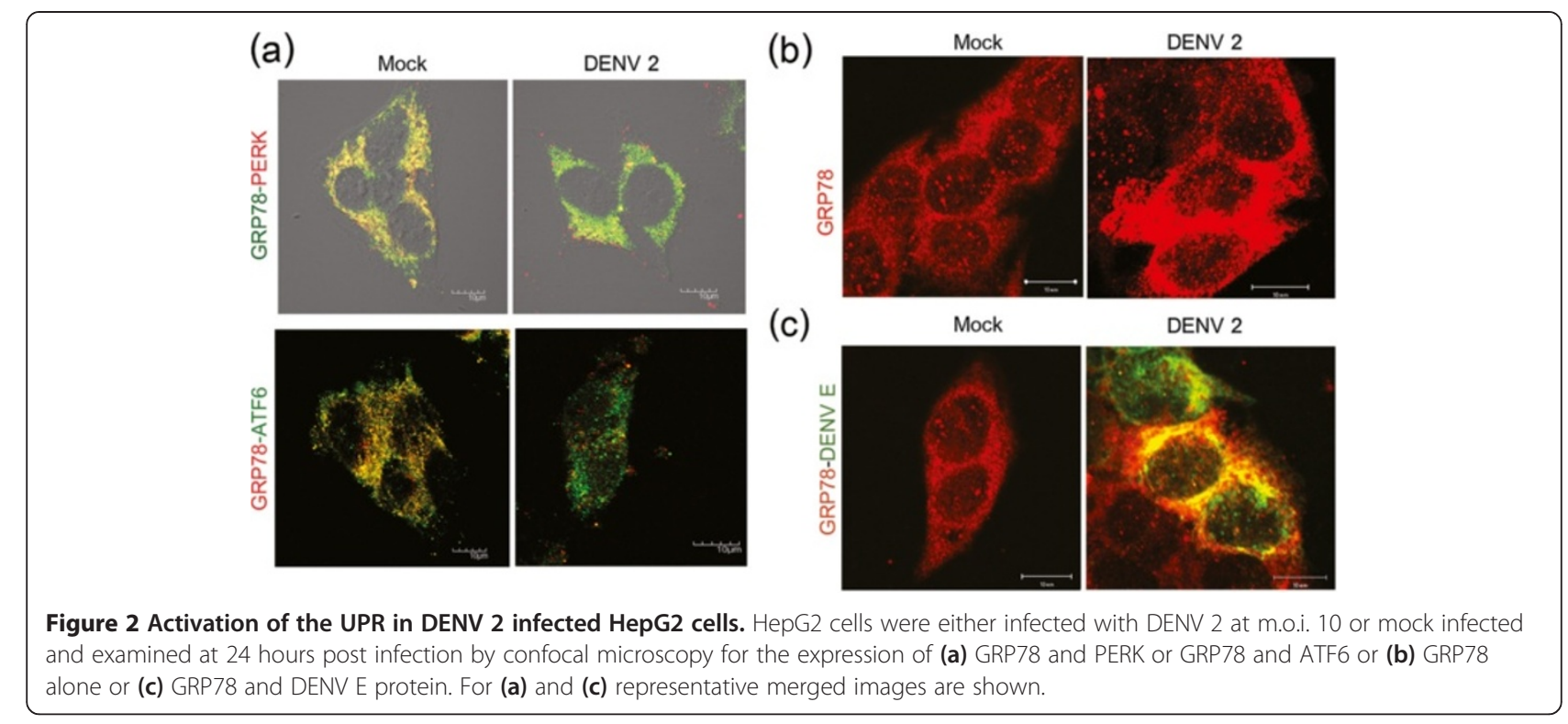

To confirm DNA fragmentation, cells were directly analyzed for DNA content by flow cytometry after propidium iodide staining and analyzed for the presence of a sub-G1 population. Results (Figure 6b) show that a significantly increased sub-G1 population

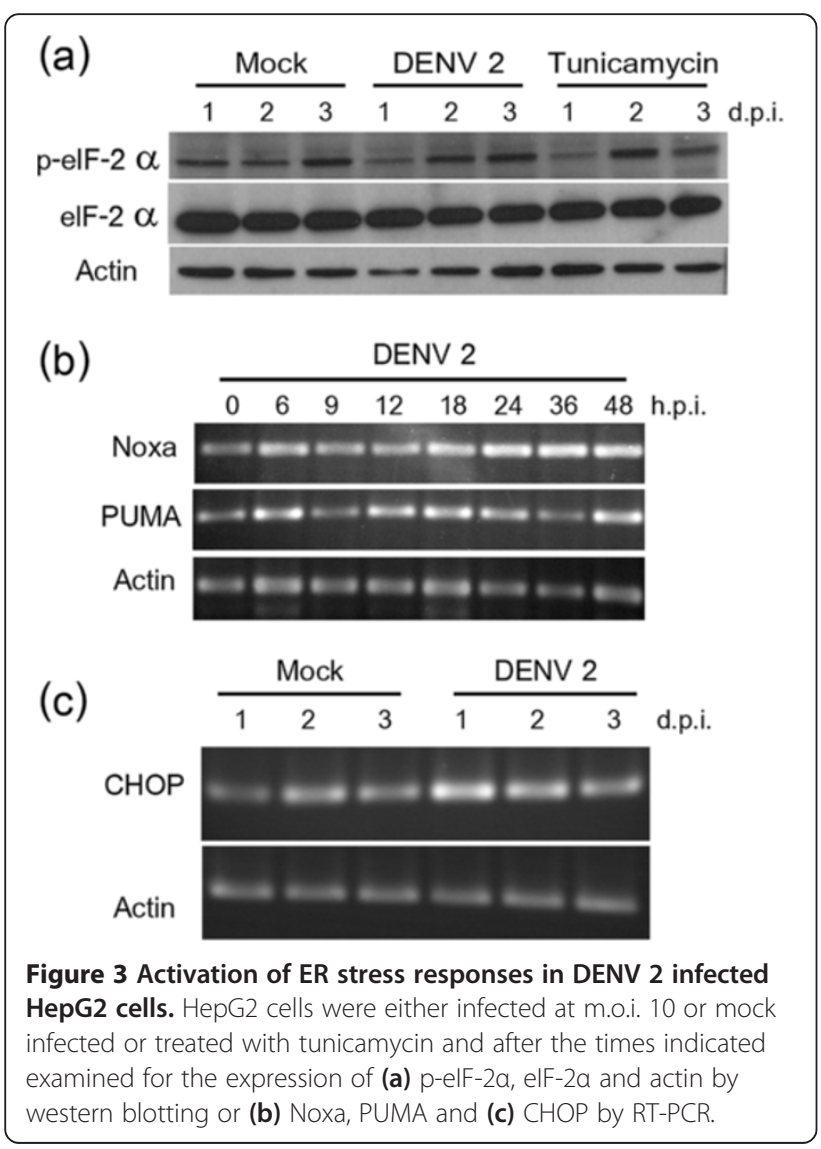

was present in infected cells as early as 24 hours post infection.

\section{Mitochondrial transmembrane potential $\left(\Delta \Psi_{m}\right)$ in DENV 2 infection}

Loss of mitochondrial function is a common hallmark of apoptosis and can be observed by a decrease in mitochondrial membrane potential. To determine whether there was a loss of mitochondrial membrane potential in response to DENV infection, HepG2 cells were either mock infected, or infected with DENV 2 at 10 p.f.u./ cell. At 24 or 48 hours post infection cells were incubated with $\operatorname{DiOC}_{6}(3)$ for 30 minutes. The cells were harvested and washed twice with PBS prior to being lysed and homogenized in deionized water. The concentration $\mathrm{DiOC}_{6}(3)$ retained was measured by fluorescent spectrophotometery at $488 \mathrm{~nm}$ excitation and $500 \mathrm{~nm}$ emission. The retention of $\mathrm{DiOC}_{6}(3)$ was compared against mock-infected cells as control. DENV 2 infected cells showed a significant $(\mathrm{p}<0.05)$ reduction in mitochondrial transmembrane potential $(\Delta \psi)$ at 48 hours post infection (Figure 6c). Direct microscopic examination of $\mathrm{DiOC}_{6}(3)$ stained cells showed an increased punctuate staining pattern as opposed to mock infected cells (Figure 6d).

\section{Activation of caspases in DENV 2 infected HepG2 cells}

To investigate the proteolytic activation of caspases, mock-infected or DENV 2 infected cells were harvested at various time points post-infection and total protein was extracted and then separated by electrophoresis on $15 \%$ SDS-polyacrylamide gels. The proteins were subsequently either transferred to nitrocellulose membranes and probed with antibodies against caspases 4, 7, 8 and 


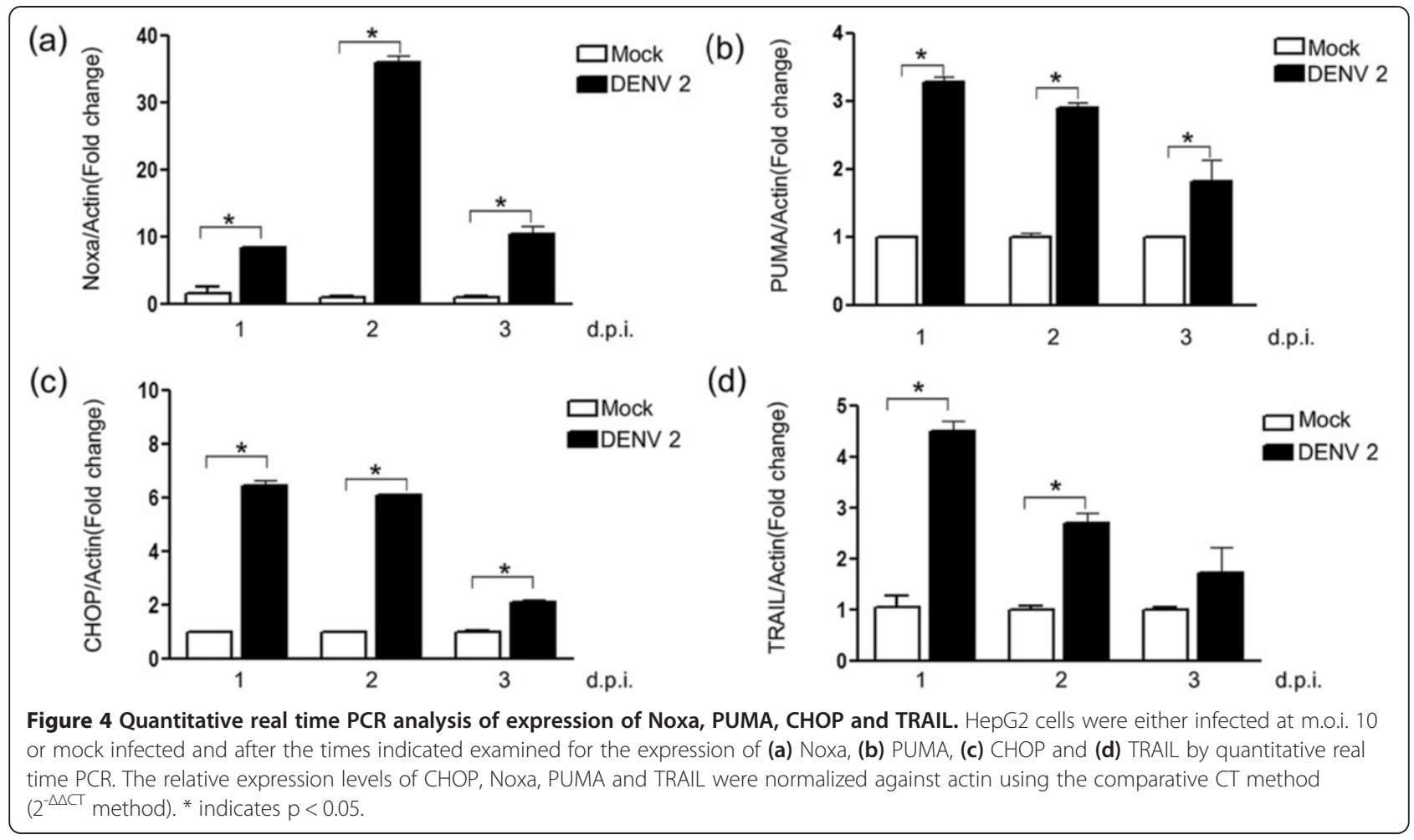

12 or used in an ELISA assay to determine the activation of caspase 9. For the western analysis, each antibody is able to detect both procaspase and active cleaved forms of the caspases and membranes were subsequently probed with a mouse monoclonal antiactin or anti GAPDH antibody as an internal control.
Western analysis (Figure 7a-d) showed the proteolytic cleavage of caspases 4, 7 and 8 in DENV 2 infected cells indicated by the presence of active forms of these proteins, while the ELISA assay confirmed the activation of caspase 9 seen in response to DENV 2 infection of HepG2 cells $(p<0.05$; Figure $7 e)$. As activation of all

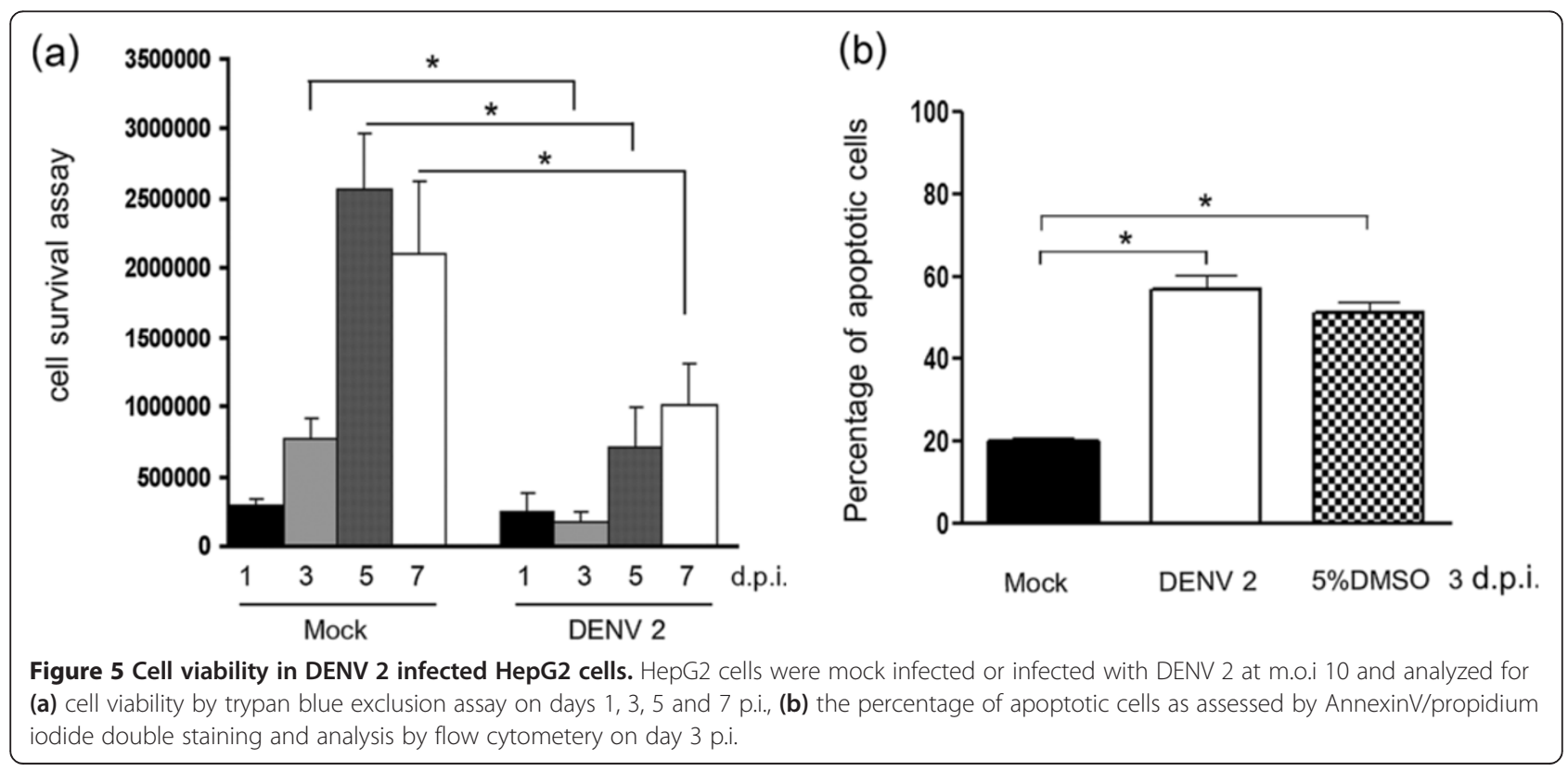




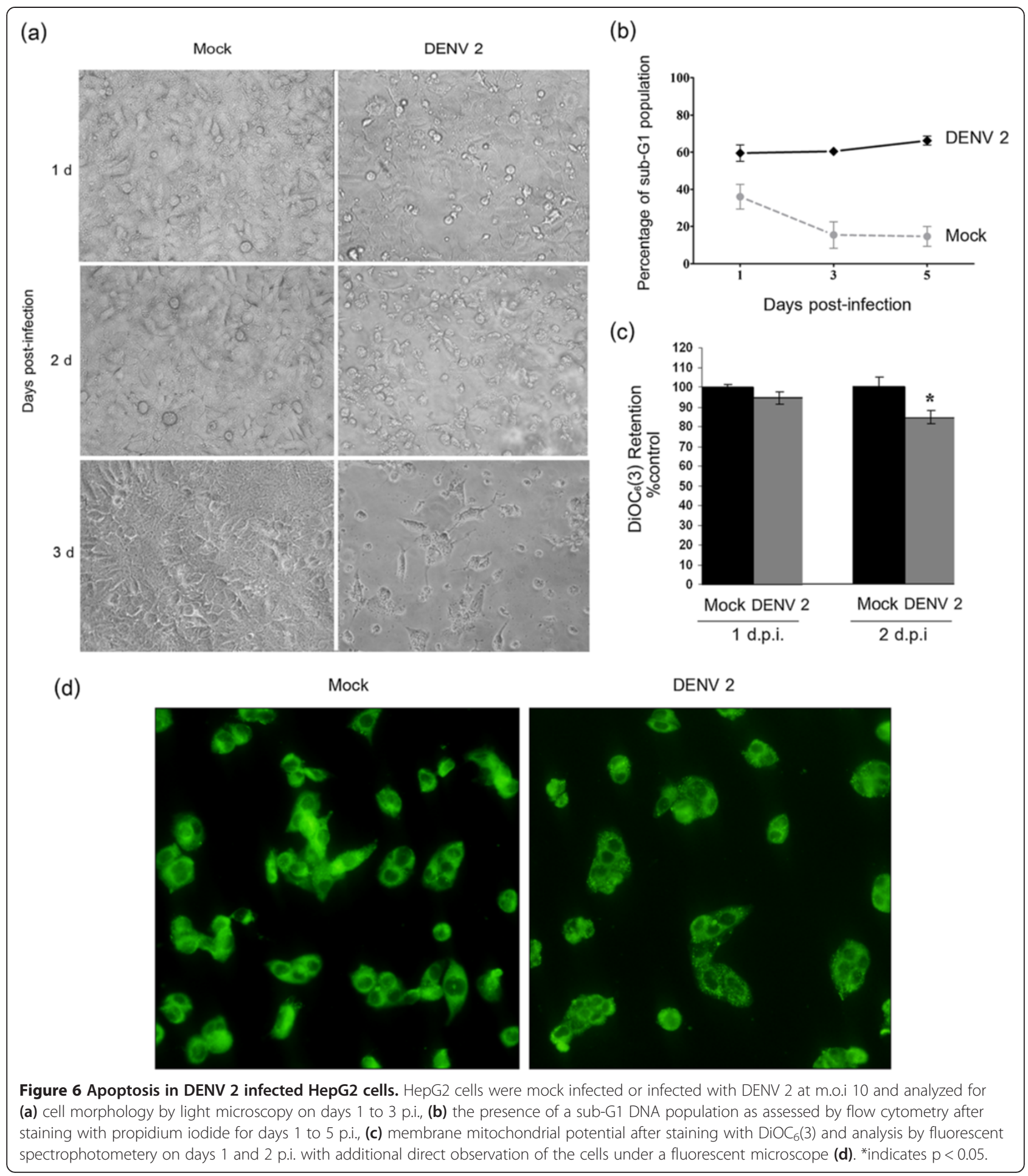

examined caspases was seen in DENV 2 infected cells, we also examined the expression of caspase 12 as a control. In human cells and cell lines, caspase 12 is normally inactive due to the inheritance of mutated alleles of this protein [49]. As expected, no activation of caspase 12 was seen in response to DENV 2 infection (Figure 7d) suggesting that activation of caspases 4, 7, 8 and 9 was a direct and specific consequence of DENV 2 infection.

\section{Expression of TRAIL}

We have previously documented increased expression of TRAIL in both HepG2 cells and in primary 


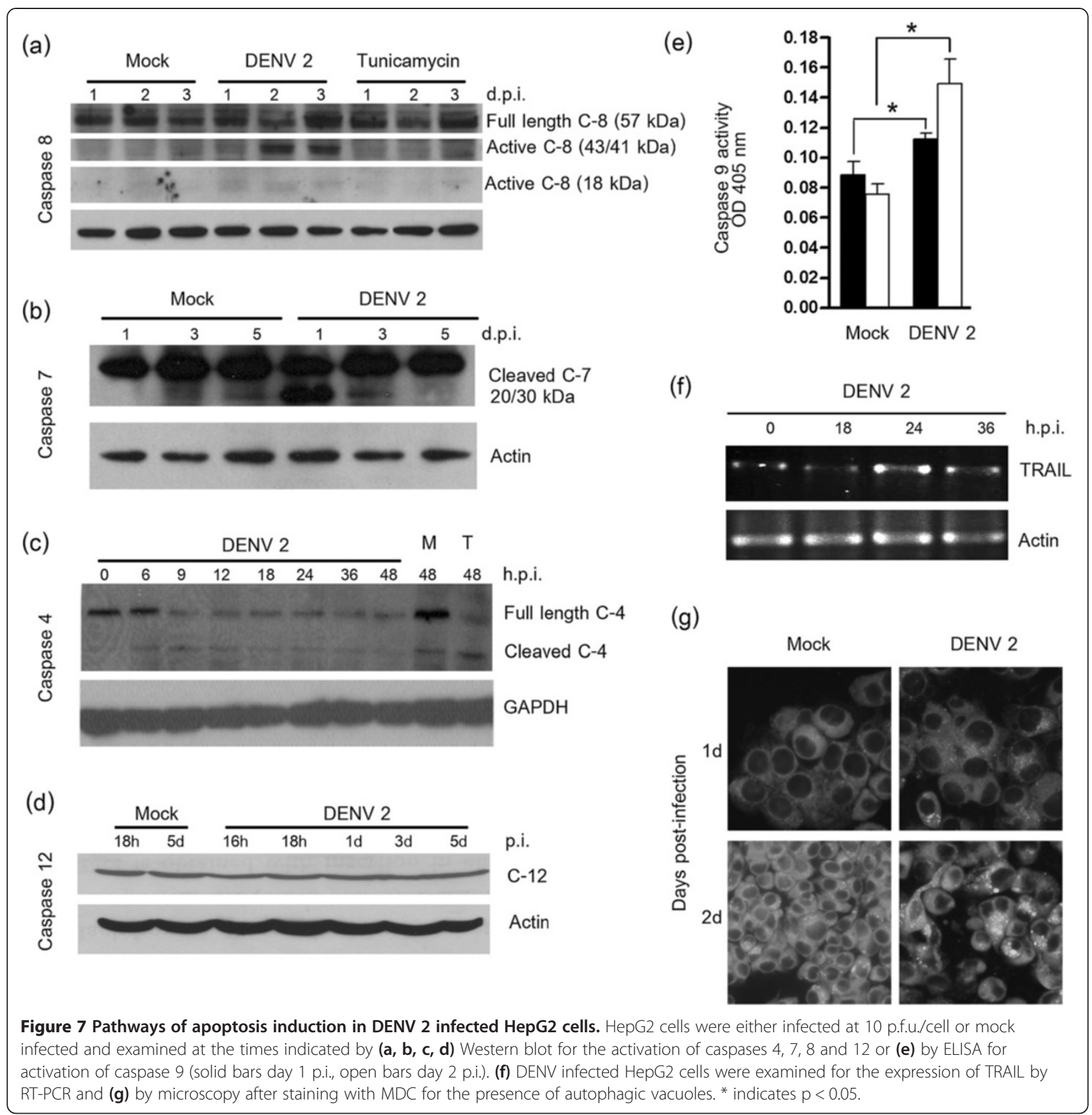

hepatocytes in response to DENV 2 infection [13]. Because of the recent retraction of the seminal paper postulating the activation of TRAIL as a critical component of the extrinsic activation of apoptosis in response to DENV infection of liver cells [50], we reconfirmed the increased expression of TRAIL in response to DENV 2 infection. Results (Figure 7f) showed an increase in TRAIL expression in response to DENV 2 infection, consistent with our earlier report [13]. The significant an early increase in TRAIL expression was confirmed by real time PCR (see Figure 4).
Induction of autophagy in response to DENV 2 infection We have previously extensively documented the induction of autophagy in response to DENV 2 infection of HepG2 [51] and other cells [52]. To confirm the activation of autophagy in response to DENV 2 in this study, HepG2 cells were either mock infected or infected with DENV 2 and stained with the acidotropic dye monodansylcadaverine (MDC) and examined under a fluorescent microscope on days 1 and 2 p.i. Results showed a notable increase in MDC positive vacuoles (Figure $7 \mathrm{~g}$ ), consistent with the activation of autophagy 
in DENV 2 infected HepG2 cells as documented previously [51].

\section{Discussion}

The involvement of the liver in dengue infections has been the subject of some controversy. However, a significant amount of evidence from primary cells, animal model studies and in vitro experiments suggests that the liver is directly involved in the pathogenesis of the disease, and that hepatocytes are a bona fide target of DENV (reviewed in [53]). Similarly, several studies in both primary [13] and transformed [16-18,54-58] liver cells have documented the induction of apoptosis in response to infection with DENV. However, the induction of apoptosis has been proposed to occur by different groups by both intrinsic (mitochondrially mediated) and extrinsic (death receptor mediated) pathways. The results seen here, specifically the activation of both caspases 8 and 9, the decrease of mitochondrial membrane potential and the up regulation of TRAIL support a model in which both intrinsic and extrinsic pathways are activated, similar to our recent report on monocytic cells where both intrinsic and extrinsic apoptosis pathways were independently activated [19]. As such, the activation of multiple, independent apoptosis pathways in response to DENV infection maybe a common mechanism, irrespective of cell type. The activation of multiple, independent apoptosis pathways in liver cells in response to DENV infection would also tend to unify the disparate studies that propose activation only through one specific pathway via one of several proposed mechanisms [16,17,56-58].

In a study in 2008 Nasirudeen and Liu [16] proposed that apoptosis in liver cells occurred via the p53 dependent activation of mitochondrially mediated (i.e. intrinsic) apoptosis. However, the proposal of p53 playing a significant role in the induction of apoptosis in liver cells is inconsistent with an earlier study which had shown the robust induction of apoptosis in the p53 negative cell line Hep3B [18].

However, as shown here, both Noxa and PUMA, which are ER stress response genes transcriptionally regulated by p53, are up-regulated in response to infection and therefore where p53 is functional in a cell, it may well play a role in mediating the apoptotic response. However, even in the absence of p53, apoptosis can still occur through the activation of non-p53 dependent pathways, again supporting our previous contention in monocytic cells that apoptosis is induced by multiple independent pathways [19].

More recently Nasirudeen and Liu proposed that caspase 1 is critical to the induction of apoptosis [17] in DENV infected cells. Caspase 1 is a human "inflammatory caspase" together with caspases 4, 5 and 12, although caspase 12 is normally inactive in humans [49]. Caspase 1 is activated by association with the so called "inflammasomes" which are large oligomeric complexes that assemble in response to signals such as the sensing of pathogen associated molecular patterns (PAMPS) or the presence of danger associated molecular patterns [59]. Recent evidence has suggested that caspase 1 activation requires the proceeding activation of caspase 4 [60] and earlier studies have suggested that caspase 4 is localized to the ER membrane and that it may be activated directly by ER stress [61]. In this way, the activation of caspase 4 as a result of ER stress and the subsequent activation of caspase 1 (with or without association of the inflammasome) might represent yet another independent pathway by which DENV infection results in apoptosis.

In other studies, the dengue capsid protein has been implicated as playing a role in the mediating the induction of intrinsic apoptosis in liver cells $[55,56,58]$. Limjindaporn and colleagues proposed that the nuclear interaction between the DENV capsid protein and the death domain associated protein Daxx is essential for the induction of apoptosis [56,58], and subsequently that the DENV capsid protein induces apoptosis through the action of either CD137 or RIPK2 [57]. However, a recent study by Jianling and colleagues [55] proposed that the interaction between DENV capsid protein and the calcium modulating cyclophilin-binding ligand (CAML) serves to subvert the apoptotic process. The contradictory results suggesting that the DENV capsid protein either promotes [56,58] or inhibits [55] apoptosis suggests that further research is required to define the function of this protein in the apoptotic process.

The induction of extrinsic apoptosis in DENV infected liver cells was originally proposed in a study that has now been retracted [50]. In the original study it was proposed that DENV infection resulted in the up-regulation of TRAIL which interacted with the Apo2L/TRAIL receptor DR5/TRAIL-R2 expressed on the surface of liver cells. This model was subsequently supported by our studies in both primary and transformed cells which showed the increased expression of TRAIL [13] as reconfirmed here. Elevated levels of TRAIL in response to DENV infection have been documented for human primary monocytes, B cells and dendritic cells [62] as well as for HUVECs (human umbilical vein endothelial cells) [63] and elevated levels of TRAIL were found in DENV infected patients in the febrile phase as compared to normal controls [62]. Warke and colleagues observed that TRAIL expression reduced viral titers in DENV infected HUVECs, and they proposed that TRAIL played an antiviral role in an apoptosis independent manner [63]. However, as was observed in the now retracted Matsuda study [50], liver cells express the Apo2L/ 
TRAIL receptor DR5/TRAIL-R2 and upon binding of TRAIL the clustered DR5 receptor complex recruits, through its cytoplasmic domain the adapter molecule FADD (Fas-associated death domain) which in turn recruits pro-caspase 8 , forming a death induced signaling complex (DISC) which directly results in the activation of caspase $8[64,65]$. Our results showing the increased expression of TRAIL and the activation of caspase 8 would therefore support the extrinsic induction of apoptosis in liver cells mediated by TRAIL, and suggests that the interaction between TRAIL and DENV infected cells is cell type specific. In this way, the elevated levels of TRAIL seen in serum of febrile DENV infected patients [62] could serve to both remove infected liver cells and protect other cells such as endothelial cells through its antiviral activities [63].

Interestingly, we observed a significant activation of caspase 9 on day 1 post infection, while caspase 8 was shown to be activated from day 2 post infection. Caspase 7 which is activated by both intrinsic and extrinsic pathways showed significant levels of activation from day 1 , and less thereafter. The delayed activation of caspase 8 (as compared to caspase 9) would also support activation of this pathway through TRAIL, which showed significant levels of expression only after 24 hours infection. Caspase activation was predominantly shown to be an early event, with apparently less activation at the later stages. However, as the cells are constantly dying as a consequence of the infection, the actively infected cells may represent a smaller and smaller proportion of the cells in culture as the non-infected cells may outgrow the infected cells.

Induction of the UPR as a consequence of DENV infection in several cell lines has been well documented $[19,43,66,67]$ and it is currently thought that it is the influx of nascent unfolded proteins to the ER as a consequence of infection is the critical event in triggering the UPR [67] and, as shown here for the first time, the UPR is activated in response to DENV infection of liver cells. Prolonged activation of the UPR is known to trigger apoptosis through a number of pathways [33,34,36-39], several of which lead directly to mitochondrially mediated (intrinsic) apoptosis and, as documented here by cleavage of caspase 9 and changes in mitochondrial membrane potential, mitochondrially mediated apoptosis is induced in DENV infected liver cells. The observation of reduced mitochondrial membrane potential in DENV infected liver cells is consistent with the observations of others [54].

Activation of PERK leads to the phosphorylation of the translation initiation factor eIF- $\alpha$, which leads to the attenuation of translation initiation with the exception of ATF4 and its downstream target CHOP (also known as GADD153) whose expression is increased when eIF- $2 \alpha$ is phosphorylated $[22,68]$, all of which were observed to occur under conditions of DENV infection of HepG2 cells. Critically, prolonged expression of CHOP, which is also a target of the other branches of the UPR $[22,68]$ results in the induction of apoptosis through a number of potential pathways, such as through the $\mathrm{Bcl} 2$ family members or through the

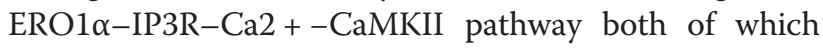
end in mitochondrially mediated apoptosis [69]. In a recent study Pena and Harris [70] investigated the induction of the unfolded protein response in response to DENV infection in human fibrosarcoma 2fTGH cells and in a number of knockout mice embryonic fibroblast (MEF) cell lines. Pena and Harris reported the time dependent modulation of the UPR, but predominantly focused on the first 12 hours of infection [70]. In particular they reported a peak of phosphorylation of eIF $2 \alpha$ at 6 hours post infection after which levels returned to mock levels, while in this study we see a down regulation at 24 hours, and a significant increase on days 2 and 3 p.i. Somewhat surprisingly, while Pena and Harris report an increase in expression of $\mathrm{CHOP}$, they report no activation of caspase 9 or and indeed, no induction of apoptosis in response to infection [70]. Given that apoptosis in response to dengue infection has been reported in numerous studies in a number of different cell types $[9,17-19,57,71-80]$ the significance of their observations remains unclear.

Studies have shown that activation of the UPR can lead to the induction of apoptosis through activation of caspase 12 [33,34]. However, caspase 12 in humans is predominantly inactive due the high occurrence of inactivating mutations in this gene in the human population [49]. As shown here, no activation of caspase 12 was seen in response to DENV infection consistent with its inactive status, however the lack of processing seen for caspase 12 confirms the specificity of activation of the other caspases examined in this study.

Induced ER stress and the activation of the UPR has been well characterized as an inducer of autophagy [81-83]. We and others have previously extensively characterized the induction of autophagy in liver cells in response to DENV infection [51,84-86], and in this study showed increased staining with MDC in DENV infected cells. MDC is a fluorescent acidotropic dye that was originally believed to specifically label autophagic vacuoles [87]. Subsequent investigations have suggested that MDC stains vacuoles late in the autophagic process [88]. While not a rigorous analysis of autophagy [89], it serves to confirm our earlier studies in the same cell line and with the same virus $[51,85]$. Autophagy is believed to be induced in response to ER stress as an attempt to decrease the stress through increased degradation of misfolded proteins [90], and studies have suggested that 
autophagy can be induced through either PERK $[90,91]$ or IRE1 [90,92]. By relieving ER stress, autophagy can therefore act in a pro-survival manner and can inhibit the onset of apoptosis [93]. However, studies have shown that prolonged activation of autophagy can promote cell death through both apparently apoptosis dependent and apoptosis independent mechanisms [93].

\section{Conclusions}

Our results show that in response to DENV infection of liver cells, there is the activation of multiple ER stress pathways and multiple modes of cell death, namely the activation of intrinsic, extrinsic and possibly inflammasome mediated apoptosis pathways, as well as the activation of autophagy which can further lead to (intrinsic) apoptosis dependent and apoptosis independent cell death. These results suggest that removal of DENV infected cells from the liver is ensured through the activation of multiple pathways.

\section{Methods}

\section{Viruses, cells and treatments}

The human hepatoma cell line HepG2 (ATCC No. HB8065) was cultivated as described previously [94]. Dengue virus serotype 2 (DENV 2; strain 16681) was propagated in the Aedes albopictus derived cell line C6/36 (ATCC No. CRL-1660). The virus was partially purified by centrifugation to remove cell debris and stored frozen at $-80^{\circ} \mathrm{C}$. Virus titer was determined by standard plaque assay as described elsewhere [95]. HepG2 cells were treated with $2 \mu \mathrm{g} / \mathrm{ml}$ tunicamycin (T7765, Sigma-Aldrich, Milwaukee, WI) as indicated.

\section{Cell morphology and viability}

HepG2 cells were seeded for 24 hours under standard growth condition, cells were either mock-infected or infected at 10 p.f.u./cell with DENV 2 for up to 7 days post infection. On days 1 to 3 p.i., cells were examined directly under an inverting light microscope (Nikon Eclipse TS100, Nikon Instruments Inc., Melville, NY) and on days $1,3,5$ and 7 p.i. the live cell number was determined by a trypan blue exclusion assay. The experiment was undertaken independently in triplicate for each day.

\section{Semi-quantitative RT-PCR}

Total RNA was isolated using TRI reagent (Molecular Research Center, Inc., Cincinnati, $\mathrm{OH}$ ) according to the manufacturer's instructions. RNA was transcribed to cDNA using ImProm- $-\mathrm{II}^{\text {tw }}$ reverse transcriptase (Promega, Madison, WI). cDNA amplifications for XBP-1, Noxa, PUMA, TRAIL, CHOP and actin were undertaken exactly as previously described, using the primers and cycle conditions described previously $[13,19]$. All products were analyzed on $2 \%$ agarose gels.

\section{Quantitative real time PCR}

Mock infected or HepG2 cells infected with DENV 2 at m.o.i. 10 were collected at the indicated time points and total RNA extracted using TRI Reagent (Molecular Research Center, Inc., Cincinnati, OH). Dnase I (Promaga, Madison, WI) was use to remove genomic DNA. Subsequently $1 \mu \mathrm{g} / \mathrm{mL}$ of the RNA was use to obtain cDNA using Oligo (dT) (Bio Basic, Inc., Ontario, Canada) and Improm-II ${ }^{\mathrm{m}}$ reverse transcriptase enzyme (Promega, Madison, WI). Quantitative real time PCR reactions were performed based on SYBR technique by using the KAPA SYBR FAST qPCR Kit 2X Master MIX (Kapa Biosystems Inc, Woburn, MA) in a Mastercycler ep realplex real time PCR system. Reactions were undertaken with an initial 3 minutes at $95^{\circ} \mathrm{C}$, followed by denaturation at $95^{\circ} \mathrm{C}$ for 10 secs, annealing at $60^{\circ} \mathrm{C}$ for 30 secs and extention at $72^{\circ} \mathrm{C}$ for 20 secs for 40 cycle. Primers used were CHOP (CHOPfw: 5'-ACCAGGAA ACGGAAACAGAGTGGT-3') and (CHOPrv: 5'-TCC TGCTTGAGCCGTTCATTCTCT-3') Noxa (Noxafw: 5' AGTCGAGTGTGCTACTCAACTCAG-3') and (Noxarv: 5' -AGGTTCCTGAGCAGAAGAGTTTGG-3') PUMA (PUMAfw: 5'-ACGACCTCAACGCACAGTACGA-3') and (PUMArv: 5'-TAATTGGGCTCCATCTCGGG-3') TRAIL (TRAILfw: 5' - CAACTCCGTCAGCTCGTTAG-3') and (TRAILrv: 5'- TGCCCACTCCTTGATGATTC -3') and Actin (Actinfw : $5^{\prime}$-ACCAACTGGGACGACATGGAGAA A-3') and (Actinrv: 5'-TAGCACAGCCTGGATAGCAAC GTA-3'). The relative expression levels of CHOP, Noxa, PUMA and TRAIL were normalized against actin using the comparative CT method ( $2^{-\Delta \Delta C T}$ method).

\section{Fluorescence confocal microscope imaging and quantitation}

Cells grown on cover slips were washed twice with $1 \mathrm{x}$ PBS followed by immersion in 100\% ice-cold methanol for 20 minutes. Cells were subsequently washed twice with $1 x$ PBS before incubation for 10 minutes with $1 \mathrm{xPBS}$ containing $0.3 \%$ Triton-X100. Cells then were blocked with 5\% FBS in 1xPBS containing 0.03\% Triton$\mathrm{X} 100$ for 1 hour at room temperature. Cells were subsequently incubated overnight with two appropriate primary antibodies at $4^{\circ} \mathrm{C}$ followed by incubation with two appropriate secondary for $1 \mathrm{hr}$ at room temperature followed by three washes with $1 \mathrm{x}$ PBS containing $0.03 \%$ Triton-X100 before mounting. Antibodies used were a 1:10 dilution of rabbit polyclonal anti GRP78 antibody (sc-13968; Santa Cruz Biotechnology Inc., Santa Cruz, CA.) followed by either a 1:50 dilution of a Rhodamine Red X conjugated goat anti rabbit IgG antibody (111295-144; Jackson, West Grove, PA) or a 1:300 dilution of a FITC conjugated donkey anti rabbit IgG antibody (sc2090; Santa Cruz Biotechnology Inc.), a 1:10 dilution of a goat polyclonal anti GRP78 antibody (sc-1050; Santa 
Cruz Biotechnology, Inc) followed by a 1:100 dilution of a Cy5 conjugated rabbit anti goat IgG antibody (81-1616; Invitrogen, Grand Island NY), a 1:200 dilution of mouse monoclonal anti dengue complex (MAB8705, Chemicon, EMD Millipore Corporation, Billerica, MA CA) followed by a 1:10 dilution of a FITC conjugated goat anti mouse IgG antibody (02-18-06; KPL, Guilford, UK), a 1:50 dilution of a mouse monoclonal anti ATF6 antibody (IMG-273; Imgenex, San Diego, CA) followed by a 1:10 dilution of a FITC conjugated goat anti mouse IgG (0218-06; KPL, Gaithersburg, MD), a 1:50 dilution of a goat polyclonal anti PERK antibody (sc-9481; Santa Cruz Biotechnology, Inc.) followed by a 1:100 dilution of a Cy5 conjugated rabbit anti-goat IgG (81-1616; Invitrogen).

Fluorescently labeled cells were observed under an Olympus FluoView 1000 (Olympus Corporation, Shinjuku-ku, Tokyo) confocal microscope equipped with Olympus FluoView software v. 1.6 or a Carl Zeiss Laser scanning system LSM510 (Carl Zeiss Advanced Imaging Microscopy, Jena, Germany) equipped with Zeiss LSM5 Image Browser software version 3.2.0115. Images were recorded in 3 channels. Fifteen fields were examined for each experiment and representative results shown. Pearson correlation coefficients for co-localization were determined as described elsewhere [51].

\section{Fluorescent microscopy}

For monodansylcadaverine (MDC) and 3,3'-dihexyloxacarbocyanine Iodide $\left(\mathrm{DiOC}_{6}(3)\right)$ staining, HepG2 cells infected with DENV 2 at $10 \mathrm{pfu} / \mathrm{cell}$ or mock infected were incubated with $0.05 \mathrm{mM} \mathrm{MDC}$ in $\mathrm{PBS}$ at $37^{\circ} \mathrm{C}$ for 1 hour or $100 \mathrm{nM} \operatorname{DiOC}_{6}(3)$ (Sigma-Aldrich, Milwaukee, WI) for 30 minutes before examination under a fluorescence microscope (Olympus BX61, Olympus).

\section{Sub G1 analysis}

To determine the DNA fragmentation upon infection in DENV 2 infected cells, HepG2 cells were either mock infected or infected with DENV 2 at 10 p.f.u./cell and incubated for up to 5 days p.i. Cells were collected on the indicated days post infection and washed with $1 \mathrm{x}$ PBS. Cells were then fixed with $70 \%$ ethanol in 1xPBS. After being washed with $1 \times$ PBS, cells were treated with $10 \mathrm{mg} / \mathrm{ml}$ RNase A for one hour, and then incubated with $1 \mathrm{mg} / \mathrm{ml}$ propidium iodide (PI) for 15 minutes before analysis by flow cytometry (BD FACSCalibur, BD Biosciences, San Jose, CA). Experiments were undertaken independently in triplicate. In data analysis cell debris was gated out and the R1 population plotted in histogram form.

\section{Western blot analysis}

Mock infected or dengue infected cells were collected by scraping at various times post infection and total proteins extracted and subjected to western blot analysis exactly as described previously $[19,51,85]$. Membranes were blocked with $5 \%$ skim milk in TBS-T at room temperature for $1 \mathrm{hr}$ and subsequently incubated for $2 \mathrm{hr}$ with an appropriate primary antibody, followed by incubation with an appropriate secondary antibody for $1 \mathrm{hr}$ at room temperature.

Primary antibodies used were mouse monoclonal antibodies against caspase 8 (1C12, Cell Signaling Technology, Inc., Danvers, MA), caspase 7 (C7, Cell Signaling Technology), actin (sc-8432, Santa Cruz Biotechnology Inc.), glyceraldehyde 3-phosphate dehydrogenase (GAPDH) (sc-32233, Santa Cruz Biotechnology, Inc.) and dengue nonstructural protein 1 (NS1) (ab41616, Abcam plc, Cambridge, UK) followed by a horseradish peroxidase (HRP) - conjugated rabbit anti-mouse IgG (A9044, SigmaAldrich) as well as rabbit polyclonal antibodies against GRP78 (SC-13968, Santa Cruz Biotechnology Inc.), phospho-eIF-2 $\alpha$ (9721, Cell Signaling Technology), eIF-2 $\alpha$ (9722, Cell Signaling Technology), caspase 12 (C2088-58, United States Biological, Swampscott, MA) followed by a horseradish peroxidase conjugated goat anti-rabbit IgG (31460, Pierce, Rockford, IL) as well as goat polyclonal antibodies directed against caspase 4 (ab27485, Abcam plc) and actin (sc-1616, Santa Cruz Biotechnology Inc.) followed by a horseradish peroxidase conjugated donkey anti-goat IgG (PA1-86326, Pierce).

The signals were developed using the ECL Plus Western Blotting Analysis kit (Amersham Pharmacia Biotech, Piscataway, NJ).

\section{Mitochondrial transmembrane potential $\left(\Delta \psi_{m}\right)$ measurement}

HepG2 cells either mock infected or infected with DENV 2 at 10 p.f.u./cell were incubated with $100 \mathrm{nM}$ 3,3'-dihexyloxacarbocyanine iodide $\left(\operatorname{DiOC}_{6}(3)\right)$; SigmaAldrich, Milwaukee, WI) for $30 \mathrm{~min}$ after which cells were washed with PBS and then harvested by centrifugation at $700 \times g$ for $5 \mathrm{~min}$. The supernatant was removed, and the pellet was resuspended and washed again in PBS. The pellet was then lysed by the addition of $600 \mu \mathrm{l}$ of deionized water followed by sonication. The concentration of retained $\mathrm{DiOC}_{6}(3)$ was read using a fluorescent spectrophotometer (FP6300, Jasco, Essex, UK) at $488 \mathrm{~nm}$ excitation and $500 \mathrm{~nm}$ emission.

\section{Annexin V/propidium iodide double staining}

HepG2 cells were either mock-infected or infected with DENV 2 at 10 p.f.u./cell. On day 3 post-infection cells were harvested by centrifugation and washed twice with PBS. The cells were double stained with $5 \mu \mathrm{l}$ of $20 \mu \mathrm{g} / \mathrm{ml}$ FITCconjugated annexin $\mathrm{V}$ and $10 \mu \mathrm{l}$ of $50 \mu \mathrm{g} / \mathrm{ml}$ propidium iodide in $400 \mu \mathrm{l}$ binding buffer (Becton Dickinson, Franklin Lakes, NJ). After 15 min cells were analyzed by flow 
cytometry (FACSCalibur, BD Biosciences, San Jose, CA) using the CELLQuest ${ }^{\mathrm{Tw}}$ software (BD Biosciences).

\section{Caspase 9 assay}

A total of $5 \times 10^{5}$ HepG2 cells were grown in 6-well tissue culture plate for 24 hours prior to mock-infection or infection with DENV 2 at 10 p.f.u./cell. Caspase 9 activity was analyzed using the Caspase 9 Colorimetric Activity Assay Kit (Chemicon, Temecula, CA). Briefly the cells were collected and lysed with kit supplied lysis buffer. Cell lysate was incubated on ice for $10 \mathrm{~min}$ prior to centrifuging at $10,000 \times g$ for $5 \mathrm{~min}$. Supernatant containing cytosolic extract was transferred to a fresh tube. Protein concentration for each sample was then analyzed by Bradford assay. The sample was incubated with caspase 9 substrate in supplied assay buffer at $37^{\circ} \mathrm{C}$ for 1 hour. Caspase 9 activity was determined by reading the optical density at $405 \mathrm{~nm}$ and normalized according to the protein concentration of each sample.

\section{Statistical analysis}

Data was analyzed using the GraphPad Prism program (GraphPad Software Inc., CA). Statistical analysis of significance was undertaken by Paired sample test using SPSS (SPSS, Inc., Chicago, IL). For all comparisons, a $\mathrm{P}$-value $\leq 0.05$ was taken as significant.

\section{Competing interests}

The authors declare they have no competing interests.

\section{Authors' contributions}

$C T, A K$ and DRS designed the study. CT, AK, SK, NW, CF, PC and PP undertook all experimental work. CT, AK and DRS drafted the initial manuscript and all co-authors reviewed the manuscript for important intellectual content and read and approved the final version.

\section{Acknowledgments}

This work was supported by grants from the Thailand Research Fund and the Office of the Higher Education Commission and Mahidol University under the National Research Universities Initiative and Mahidol University. S.K. and N.W. are supported by TRF and Mahidol University (Thai Royal Golden Jubilee) PhD Scholarships. C.F. is supported by a Thai Royal Golden Jubilee PhD Scholarship. The funding agencies had no role in the study design, analysis and interpretation of data or in the decision to submit the article for publication.

Received: 20 February 2013 Accepted: 11 September 2013 Published: 14 September 2013

\section{References}

1. Halstead SB: Antibody, macrophages, dengue virus infection, shock, and hemorrhage: a pathogenetic cascade. Rev Infect Dis 1989, 11 (Suppl 4):S830-S839.

2. Bhatt $S$, Gething PW, Brady OJ, Messina JP, Farlow AW, Moyes $C L$, Drake JM, Brownstein JS, Hoen AG, Sankoh O, et al: The global distribution and burden of dengue. Nature 2013, 496:504-507.

3. Mohan B, Patwari AK, Anand VK: Hepatic dysfunction in childhood dengue infection. J Trop Pediatr 2000, 46:40-43.

4. Nguyen $T L$, Nguyen TH, Tieu NT: The impact of dengue haemorrhagic fever on liver function. Res Virol 1997, 148:273-277.

5. Wahid SF, Sanusi S, Zawawi MM, Ali RA: A comparison of the pattern of liver involvement in dengue hemorrhagic fever with classic dengue fever. Southeast Asian J Trop Med Public Health 2000, 31:259-263.
6. Bhatnagar J, Blau DM, Shieh WJ, Paddock CD, Drew C, Liu L, Jones T, Patel M, Zaki SR: Molecular detection and typing of dengue viruses from archived tissues of fatal cases by rt-PCR and sequencing: diagnostic and epidemiologic implications. Am J Trop Med Hyg 2012, 86:335-340.

7. Hall WC, Crowell TP, Watts DM, Barros VL, Kruger H, Pinheiro F, Peters CJ: Demonstration of yellow fever and dengue antigens in formalin-fixed paraffin-embedded human liver by immunohistochemical analysis. Am J Trop Med Hyg 1991, 45:408-417.

8. Jessie K, Fong MY, Devi S, Lam SK, Wong KT: Localization of dengue virus in naturally infected human tissues, by immunohistochemistry and in situ hybridization. J Infect Dis 2004, 189:1411-1418.

9. Limonta D, Capo V, Torres G, Perez AB, Guzman MG: Apoptosis in tissues from fatal dengue shock syndrome. J Clin Virol 2007, 40:50-54.

10. Couvelard A, Marianneau P, Bedel C, Drouet MT, Vachon F, Henin D, Deubel $\checkmark$ : Report of a fatal case of dengue infection with hepatitis: demonstration of dengue antigens in hepatocytes and liver apoptosis. Hum Pathol 1999, 30:1106-1110.

11. Huerre MR, Lan NT, Marianneau P, Hue NB, Khun H, Hung NT, Khen NT, Drouet MT, Huong VT, Ha DQ, et al: Liver histopathology and biological correlates in five cases of fatal dengue fever in Vietnamese children. Virchows Arch 2001, 438:107-115.

12. Marianneau P, Steffan AM, Royer C, Drouet MT, Jaeck D, Kirn A, Deubel V: Infection of primary cultures of human Kupffer cells by Dengue virus: no viral progeny synthesis, but cytokine production is evident. J Virol 1999, 73:5201-5206.

13. Suksanpaisan L, Cabrera-Hernandez A, Smith DR: Infection of human primary hepatocytes with dengue virus serotype 2. J Med Virol 2007, 79:300-307

14. Jan JT, Chen BH, Ma SH, Liu Cl, Tsai HP, Wu HC, Jiang SY, Yang KD, Shaio MF: Potential dengue virus-triggered apoptotic pathway in human neuroblastoma cells: arachidonic acid, superoxide anion, and NF-kappaB are sequentially involved. J Virol 2000, 74:8680-8691.

15. Marianneau P, Cardona A, Edelman L, Deubel V, Despres P: Dengue virus replication in human hepatoma cells activates NF-kappaB which in turn induces apoptotic cell death. J Virol 1997, 71:3244-3249.

16. Nasirudeen AM, Liu DX: Induction of p53-dependent and mitochondriamediated cell death pathway by dengue virus infection of human and animal cells. Microbes Infect 2008, 10:1124-1132.

17. Nasirudeen AM, Liu DX: Gene expression profiling by microarray analysis reveals an important role for caspase- 1 in dengue virus-induced p53mediated apoptosis. J Med Virol 2009, 81:1069-1081.

18. Thongtan T, Panyim S, Smith DR: Apoptosis in dengue virus infected liver cell lines HepG2 and Hep3B. J Med Virol 2004, 72:436-444.

19. Klomporn P, Panyasrivanit M, Wikan N, Smith DR: Dengue infection of monocytic cells activates ER stress pathways, but apoptosis is induced through both extrinsic and intrinsic pathways. Virology 2011, 409:189-197.

20. Zimmermann KC, Bonzon C, Green DR: The machinery of programmed cell death. Pharmacol Ther 2001, 92:57-70.

21. Xu C, Bailly-Maitre B, Reed JC: Endoplasmic reticulum stress: cell life and death decisions. J Clin Invest 2005, 115:2656-2664.

22. Rutkowski DT, Kaufman RJ: A trip to the ER: coping with stress. Trends Cell Biol 2004, 14:20-28.

23. Schroder M: Endoplasmic reticulum stress responses. Cell Mol Life Sci 2008, 65:862-894.

24. Lee K, Tirasophon W, Shen X, Michalak M, Prywes R, Okada T, Yoshida H, Mori K, Kaufman RJ: IRE1-mediated unconventional mRNA splicing and S2P-mediated ATF6 cleavage merge to regulate XBP1 in signaling the unfolded protein response. Genes Dev 2002, 16:452-466.

25. Liu CY, Schroder M, Kaufman RJ: Ligand-independent dimerization activates the stress response kinases IRE1 and PERK in the lumen of the endoplasmic reticulum. J Biol Chem 2000, 275:24881-24885.

26. Baumeister P, Luo S, Skarnes WC, Sui G, Seto E, Shi Y, Lee AS: Endoplasmic reticulum stress induction of the Grp78/BiP promoter: activating mechanisms mediated by YY1 and its interactive chromatin modifiers. Mol Cell Biol 2005, 25:4529-4540.

27. Li J, Lee AS: Stress induction of GRP78/BiP and its role in cancer. Curr Mol Med 2006, 6:45-54.

28. Morris JA, Dorner AJ, Edwards CA, Hendershot LM, Kaufman RJ: Immunoglobulin binding protein (BiP) function is required to protect cells from endoplasmic reticulum stress but is not required for the secretion of selective proteins. J Biol Chem 1997, 272:4327-4334. 
29. Scheuner D, Song B, McEwen E, Liu C, Laybutt R, Gillespie P, Saunders T, Bonner-Weir S, Kaufman RJ: Translational control is required for the unfolded protein response and in vivo glucose homeostasis. Mol Cell 2001, 7:1165-1176.

30. Reddy RK, Mao C, Baumeister P, Austin RC, Kaufman RJ, Lee AS: Endoplasmic reticulum chaperone protein GRP78 protects cells from apoptosis induced by topoisomerase inhibitors: role of ATP binding site in suppression of caspase-7 activation. J Biol Chem 2003, 278:20915-20924.

31. Malhotra JD, Kaufman RJ: The endoplasmic reticulum and the unfolded protein response. Semin Cell Dev Biol 2007, 18:716-731.

32. Rao RV, Ellerby HM, Bredesen DE: Coupling endoplasmic reticulum stress to the cell death program. Cell Death Differ 2004, 11:372-380.

33. Nakagawa T, Yuan J: Cross-talk between two cysteine protease families. Activation of caspase-12 by calpain in apoptosis. J Cell Biol 2000, 150:887-894.

34. Nakagawa T, Zhu H, Morishima N, Li E, Xu J, Yankner BA, Yuan J: Caspase12 mediates endoplasmic-reticulum-specific apoptosis and cytotoxicity by amyloid-beta. Nature 2000, 403:98-103.

35. McCullough KD, Martindale JL, Klotz LO, Aw TY, Holbrook NJ: Gadd153 sensitizes cells to endoplasmic reticulum stress by down-regulating $\mathrm{Bcl} 2$ and perturbing the cellular redox state. Mol Cell Biol 2001, 21:1249-1259.

36. Marciniak SJ, Yun CY, Oyadomari S, Novoa I, Zhang Y, Jungreis R, Nagata K, Harding HP, Ron D: CHOP induces death by promoting protein synthesis and oxidation in the stressed endoplasmic reticulum. Genes Dev 2004, 18:3066-3077.

37. Urano F, Wang X, Bertolotti A, Zhang Y, Chung P, Harding HP, Ron D: Coupling of stress in the ER to activation of JNK protein kinases by transmembrane protein kinase IRE1. Science 2000, 287:664-666.

38. Crompton M: The mitochondrial permeability transition pore and its role in cell death. Biochem J 1999, 341(Pt 2):233-249.

39. Shibue T, Taniguchi T: BH3-only proteins: integrated control point of apoptosis. Int J Cancer 2006, 119:2036-2043.

40. Li J, Lee B, Lee AS: Endoplasmic reticulum stress-induced apoptosis: multiple pathways and activation of p53-up-regulated modulator of apoptosis (PUMA) and NOXA by p53. J Biol Chem 2006, 281:7260-7270.

41. Back SH, Lee K, Vink E, Kaufman RJ: Cytoplasmic IRE1alpha-mediated XBP1 mRNA splicing in the absence of nuclear processing and endoplasmic reticulum stress. J Biol Chem 2006, 281:18691-18706.

42. Shang J: Quantitative measurement of events in the mammalian unfolded protein response. Methods 2005, 35:390-394.

43. Umareddy I, Pluquet O, Wang QY, Vasudevan SG, Chevet E, Gu F: Dengue virus serotype infection specifies the activation of the unfolded protein response. Virol J 2007, 4:91

44. Shen $X$, Zhang K, Kaufman RJ: The unfolded protein response-a stress signaling pathway of the endoplasmic reticulum. J Chem Neuroanat 2004, 28:79-92.

45. Wati S, Soo ML, Zilm P, Li P, Paton AW, Burrell CJ, Beard M, Carr JM: Dengue virus infection induces upregulation of GRP78, which acts to chaperone viral antigen production. J Virol 2009, 83:12871-12880

46. Jindadamrongwech S, Thepparit C, Smith DR: Identification of GRP 78 (BiP) as a liver cell expressed receptor element for dengue virus serotype 2 . Arch Virol 2004, 149:915-927.

47. Limjindaporn T, Wongwiwat W, Noisakran S, Srisawat C, Netsawang J, Puttikhunt C, Kasinrerk W, Avirutnan P, Thiemmeca S, Sriburi R, et al: Interaction of dengue virus envelope protein with endoplasmic reticulum-resident chaperones facilitates dengue virus production. Biochem Biophys Res Commun 2009, 379:196-200.

48. Upanan S, Kuadkitkan A, Smith DR: Identification of dengue virus binding proteins using affinity chromatography. J Virol Methods 2008, 151:325-328

49. Fischer $\mathrm{H}$, Koenig $U$, Eckhart L, Tschachler E: Human caspase 12 has acquired deleterious mutations. Biochem Biophys Res Commun 2002, 293:722-726.

50. Matsuda T, Almasan A, Tomita M, Tamaki K, Saito M, Tadano M, Yagita H, Ohta T, Mori N: Dengue virus-induced apoptosis in hepatic cells is partly mediated by Apo2 ligand/tumour necrosis factor-related apoptosisinducing ligand (Journal of General Virology (2005) 86 (1055-1065)). J Gen Virol 2010, 91:2658.

51. Panyasrivanit M, Khakpoor A, Wikan N, Smith DR: Co-localization of constituents of the dengue virus translation and replication machinery with amphisomes. J Gen Virol 2009, 90:448-456.
52. Panyasrivanit M, Greenwood MP, Murphy D, Isidoro C, Auewarakul P, Smith DR: Induced autophagy reduces virus output in dengue infected monocytic cells. Virology 2011, 418:74-84

53. Smith DR, Khakpoor A: Involvement of the liver in dengue infections. Dengue Bull 2009, 33:75-86.

54. El-Bacha T, Midlej V, Pereira da Silva AP, L S d C, M B, Galina A, Da Poian AT: Mitochondrial and bioenergetic dysfunction in human hepatic cells infected with dengue 2 virus. Biochim Biophys Acta 2007, 1772:1158-1166.

55. Jianling $L$, Rongjie $H$, Weiyong L, Zhaoni C, Shijun Z, Renbin H: Dengue virus utilizes calcium modulating cyclophilin-binding ligand to subvert apoptosis. Biochem Biophys Res Commun 2012, 418:622-627.

56. Limjindaporn T, Netsawang J, Noisakran S, Thiemmeca S, Wongwiwat W, Sudsaward S, Avirutnan P, Puttikhunt C, Kasinrerk W, Sriburi R, et al: Sensitization to Fas-mediated apoptosis by dengue virus capsid protein. Biochem Biophys Res Commun 2007, 362:334-339.

57. Nagila A, Netsawang J, Srisawat C, Noisakran S, Morchang A, Yasamut U, Puttikhunt C, Kasinrerk W, Malasit P, Yenchitsomanus PT, Limjindaporn T: Role of CD137 signaling in dengue virus-mediated apoptosis. Biochem Biophys Res Commun 2011, 410:428-433.

58. Netsawang J, Noisakran S, Puttikhunt C, Kasinrerk W, Wongwiwat W, Malasit $P$, Yenchitsomanus PT, Limjindaporn T: Nuclear localization of dengue virus capsid protein is required for DAXX interaction and apoptosis. Virus Res 2010, 147:275-283.

59. Franchi L, Munoz-Planillo R, Nunez G: Sensing and reacting to microbes through the inflammasomes. Nat Immunol 2012, 13:325-332.

60. Sollberger G, Strittmatter GE, Kistowska M, French LE, Beer HD: Caspase-4 is required for activation of inflammasomes. J Immuno/ 2012, 188:1992-2000.

61. Hitomi J, Katayama T, Eguchi Y, Kudo T, Taniguchi M, Koyama Y, Manabe T, Yamagishi S, Bando $Y$, Imaizumi $K$, et al: Involvement of caspase-4 in endoplasmic reticulum stress-induced apoptosis and Abeta-induced cell death. J Cell Biol 2004, 165:347-356.

62. Becerra A, Warke RV, Martin K, Xhaja K, De-Bosch N, Rothman AL, Bosch I: Gene expression profiling of dengue infected human primary cells identifies secreted mediators in vivo. J Med Virol 2009, 81:1403-1411.

63. Warke RV, Martin KJ, Giaya K, Shaw SK, Rothman AL, Bosch I: TRAIL is a novel antiviral protein against dengue virus. J Virol 2008, 82:555-564.

64. Kischkel FC, Lawrence DA, Chuntharapai A, Schow P, Kim KJ, Ashkenazi A: Apo2L/TRAIL-dependent recruitment of endogenous FADD and caspase8 to death receptors 4 and 5 . Immunity 2000, 12:611-620.

65. Sprick MR, Weigand MA, Rieser E, Rauch $C T$, Juo P, Blenis J, Krammer PH, Walczak H: FADD/MORT1 and caspase- 8 are recruited to TRAIL receptors 1 and 2 and are essential for apoptosis mediated by TRAIL receptor 2 . Immunity 2000, 12:599-609.

66. Paradkar PN, Ooi EE, Hanson BJ, Gubler DJ, Vasudevan SG: Unfolded protein response (UPR) gene expression during antibody-dependent enhanced infection of cultured monocytes correlates with dengue disease severity. Biosci Rep 2011, 31:221-230.

67. Yu CY, Hsu YW, Liao CL, Lin YL: Flavivirus infection activates the XBP1 pathway of the unfolded protein response to cope with endoplasmic reticulum stress. J Virol 2006, 80:11868-11880.

68. Wu J, Kaufman RJ: From acute ER stress to physiological roles of the Unfolded Protein Response. Cell Death Differ 2006, 13:374-384.

69. Tabas I, Ron D: Integrating the mechanisms of apoptosis induced by endoplasmic reticulum stress. Nat Cell Biol 2011, 13:184-190.

70. Peña J, Harris E: Dengue virus modulates the unfolded protein response in a time-dependent manner. J Biol Chem 2011, 286:14226-14236.

71. Avirutnan P, Malasit P, Seliger B, Bhakdi S, Husmann M: Dengue virus infection of human endothelial cells leads to chemokine production, complement activation, and apoptosis. J Immunol 1998, 161:6338-6346.

72. Brown MG, Huang YY, Marshall JS, King CA, Hoskin DW, Anderson R: Dramatic caspase-dependent apoptosis in antibody-enhanced dengue virus infection of human mast cells. J Leukoc Biol 2009, 85:71-80.

73. Despres P, Flamand M, Ceccaldi PE, Deubel V: Human isolates of dengue type 1 virus induce apoptosis in mouse neuroblastoma cells. J Virol 1996, 70:4090-4096.

74. Espina LM, Valero NJ, Hernandez JM, Mosquera JA: Increased apoptosis and expression of tumor necrosis factor-alpha caused by infection of cultured human monocytes with dengue virus. Am J Trop Med Hyg 2003, 68:48-53.

75. Liao $\mathrm{H}, \mathrm{Xu}$ J, Huang J: FasL/Fas pathway is involved in dengue virus induced apoptosis of the vascular endothelial cells. J Med Virol 2010, 82:1392-1399 
76. Marianneau P, Flamand M, Deubel V, Despres P: Induction of programmed cell death (apoptosis) by dengue virus in vitro and in vivo. Acta Cient Venez 1998, 49(Suppl 1):13-17.

77. Mongkolsapaya J, Dejnirattisai W, Xu XN, Vasanawathana S, Tangthawornchaikul N, Chairunsri A, Sawasdivorn S, Duangchinda T, Dong $\mathrm{T}$, Rowland-Jones S, et al: Original antigenic sin and apoptosis in the pathogenesis of dengue hemorrhagic fever. Nat Med 2003, 9:921-927.

78. Morchang A, Yasamut U, Netsawang J, Noisakran S, Wongwiwat W, Songprakhon P, Srisawat C, Puttikhunt C, Kasinrerk W, Malasit P, et al: Cell death gene expression profile: role of RIPK2 in dengue virus-mediated apoptosis. Virus Res 2011, 156:25-34.

79. Tuiskunen A, Monteil V, Plumet S, Boubis L, Wahlström M, Duong V, Buchy P, Lundkvist A, Tolou H, Leparc-Goffart I: Phenotypic and genotypic characterization of dengue virus isolates differentiates dengue fever and dengue hemorrhagic fever from dengue shock syndrome. Arch Virol 2011, 156:2023-2032.

80. Torrentes-Carvalho A, Azeredo EL, Reis SR, Miranda AS, Gandini M, Barbosa LS, Kubelka CF: Dengue-2 infection and the induction of apoptosis in human primary monocytes. Mem Inst Oswaldo Cruz 2009, 104:1091-1099.

81. Kawakami T, Inagi R, Takano H, Sato S, Ingelfinger JR, Fujita T, Nangaku M: Endoplasmic reticulum stress induces autophagy in renal proximal tubular cells. Nephrol Dial Transplant 2009, 24:2665-2672.

82. Yorimitsu T, Klionsky DJ: Endoplasmic reticulum stress: a new pathway to induce autophagy. Autophagy 2007, 3:160-162.

83. Yorimitsu T, Nair U, Yang Z, Klionsky DJ: Endoplasmic reticulum stress triggers autophagy. J Biol Chem 2006, 281:30299-30304.

84. Heaton NS, Randall G: Dengue virus-induced autophagy regulates lipid metabolism. Cell Host Microbe 2010, 8:422-432.

85. Khakpoor A, Panyasrivanit M, Wikan N, Smith DR: A role for autophagolysosomes in dengue virus 3 production in HepG2 cells. J Gen Virol 2009, 90:1093-1103.

86. Lee YR, Lei HY, Liu MT, Wang JR, Chen SH, Jiang-Shieh YF, Lin YS, Yeh TM, Liu CC, Liu HS: Autophagic machinery activated by dengue virus enhances virus replication. Virology 2008, 374:240-248.

87. Biederbick A, Kern HF, Elsasser HP: Monodansylcadaverine (MDC) is a specific in vivo marker for autophagic vacuoles. Eur J Cell Biol 1995, $66: 3-14$.

88. Bampton ET, Goemans CG, Niranjan D, Mizushima N, Tolkovsky AM: The dynamics of autophagy visualized in live cells: from autophagosome formation to fusion with endo/lysosomes. Autophagy 2005, 1:23-36.

89. Klionsky DJ, et al: Guidelines for the use and interpretation of assays for monitoring autophagy. Autophagy 2012, 4:445-544.

90. Ding WX, Yin XM: Sorting, recognition and activation of the misfolded protein degradation pathways through macroautophagy and the proteasome. Autophagy 2008, 4:141-150.

91. Kouroku Y, Fujita E, Tanida I, Ueno T, Isoai A, Kumagai H, Ogawa S, Kaufman RJ, Kominami E, Momoi T: ER stress (PERK/elF2alpha phosphorylation) mediates the polyglutamine-induced LC3 conversion, an essential step for autophagy formation. Cell Death Differ 2007, 14:230-239.

92. Ogata M, Hino S, Saito A, Morikawa K, Kondo S, Kanemoto S, Murakami T, Taniguchi M, Tanii I, Yoshinaga K, et al: Autophagy is activated for cell survival after endoplasmic reticulum stress. Mol Cell Biol 2006, 26:9220-9231.

93. Eisenberg-Lerner A, Bialik S, Simon HU, Kimchi A: Life and death partners: apoptosis, autophagy and the cross-talk between them. Cell Death Differ 2009, 16:966-975.

94. Thepparit C, Phoolcharoen W, Suksanpaisan L, Smith DR: Internalization and propagation of the dengue virus in human hepatoma (HepG2) cells. Intervirology 2004, 47:78-86.

95. Sithisarn P, Suksanpaisan L, Thepparit C, Smith DR: Behavior of the dengue virus in solution. J Med Virol 2003, 71:532-539.

doi:10.1186/1756-0500-6-372

Cite this article as: Thepparit et al:: Dengue 2 infection of HepG2 liver cells results in endoplasmic reticulum stress and induction of multiple pathways of cell death. BMC Research Notes 2013 6:372.

\section{Submit your next manuscript to BioMed Central and take full advantage of:}

- Convenient online submission

- Thorough peer review

- No space constraints or color figure charges

- Immediate publication on acceptance

- Inclusion in PubMed, CAS, Scopus and Google Scholar

- Research which is freely available for redistribution

Submit your manuscript at www.biomedcentral.com/submit
C) Biomed Central 